$\begin{gathered}\text { Науковий вісник НлтУ України } \\ \text { Scientific Bulletin of UNFU } \\ \text { http://nv.nltu.edu.ua }\end{gathered}$
$\begin{aligned} & \text { https://doi.org/10.15421/40280312 } \\ & \text { Article received 12.04.2018 p. } \\ & \text { Article accepted 26.04.2018 p. } \\ & \text { удк 582.998.2:712.42(477.63) }\end{aligned}$

Т. Ф. Чипиляк, І. І. Коршиков, О. М. Лещенюк, О. О. Лінкевич

Криворізький ботанічний сад НАН Украӥни, м. Кривий Ріг, Україна

\title{
ХРИЗАНТЕМА ДРІБНОКВІТКОВА В ЛАНДШАФТНИХ КОМПОЗИЦІЯХ НА КРИВОРІЖЖІ
}

\begin{abstract}
Невід'ємним компонентом садово-паркових насаджень $є$ квітникове оформлення, як художній елемент благоустрою. Колекція Chrysanthemum indicum L. Криворізького ботанічного саду НАН України (КБС) складається з 98 різноманітних культиварів, які в ландшафтному дизайні цінують за декоративність та універсальність використання. Визначено методи i прийоми практичного використання садової хризантеми в ландшафтах Криворізького регіону. Для цього на території КБС було створено осінній квітник "Бал хризантем" площею 0,25 га у межах вже наявних мікроландшафтних дендрокомпозицій. Під час вибору ділянки було враховано такі вимоги: огляд експозиції з усіх боків, сприятливі грунтово-кліматичні умови території Саду, наявність доріжок та місць короткочасного відпочинку. Рослини хризантеми розміщено в рівновазі відносно центру і висаджено невеликими кольоровими плямами в одній площині з нечіткими кордонами. На експозиції сорти було поєднано за забарвленням квітки, шириною та висотою рослини з використанням принципу чергування яскравих картин 3 паузами або інтервалами. Використання сортів Chrysanthemum indicum як монокультури (КБС - моносад) та як доповнення до інших рослин (м. Кривий Ріг, Криворізький район - осінні квітники, бордюрні посадки, обрамлення хвойних рослин) сприяє створенню сучасних високодекоративних культур-фітоценозів на території Криворіжжя.
\end{abstract}

Ключові слова: садова хризантема; моносад; фітоландшафти; Криворізький регіон.

Вступ. Розвиток сучасного міста потребує нових моделей та підходів до впровадження систем озеленення. У формуванні неповторності та виразності ландшафту міста одну з головних ролей відіграють композиції з рослинності, які мають об'єднати й привести до логічної завершеності всі його елементи та забезпечити комфорт і гармонію для людини (Kucheryavyy, 2005; D'yachenko, 2010). Невід'ємним компонентом садовопаркових насаджень $\epsilon$ квітникове оформлення, яке нині сприймають як художній елемент благоустрою. 3 огляду на це інтродукція та використання квітниково-декоративних рослин займає чільне місце в науковій та практичній діяльності ботанічних садів. Вміння показати багаті за асортиментом колекції рослин, їх створення та формування на екологічних принципах та засадах мистецтва садової архітектури є досить складною справою і потребує конкретних знань. Сьогодні тільки плідна співпраця міської адміністрації i науковців, які займаються діяльністю, пов'язаною з озелененням, може вирішити означені проблеми (Наказ від 31 травня 2007 року N 32 Міністерства 3 питань житлово-комунального господарства України "Про затвердження Рекомендацій із розроблення правил благоустрою території населеного пункту"). Наразі фонди декоративних рослин, зібраних у ботанічних садах, є джерелом матеріалу для вирішення виробничих потреб відповідної сфери діяльності і $є$ надзвичайно привабливими для ек- спозиційної роботи та, окрім рекреаційно-естетичного та пізнавального, мають висококультурне значення (Cherevchenko, 2002; Chypylyak et al., 2014).

Криворізький ботанічний сад (загальна площа 52,4 га) є науковою установою Національної академії наук України (далі КБС), яка за 40 років свого існування забезпечує збереження біологічного різноманіття рослин регіональної та світової флори, сприяє створенню колекцій декоративно-цінних рослин, зокрема i Chrysanthemum indicum L. У ландшафтному фітодизайні хризантему цінують за декоративність та універсальність у використанні. Вона дуже добре розмножується та витримує пересаджування під час бутонізації і масового цвітіння, стійка до шкідників, хвороб та інших негативних чинників. I особливо цінне іiі квітування восени, коли завдяки добору сортів хризантеми різних декоративних груп та термінів цвітіння можна подовжити час милування осінніми квітами.

Мета дослідження - визначити методи і прийоми практичного використання представників Chrysanthemum indicum у формуванні ландшафтного простору Криворізького регіону.

Матеріал і методи дослідження. Об'єкт досліджень - представники роду хризантема (Dendranthema (DC). Desmoul., Chrysanthemum L.) колекції КБС НАН України, які $є$ перспективною групою для формування осінніх квітникових моносадів. Дослідження проводили за

\section{Інформація про авторів:}

Чипиляк Тетяна Федорівна, канд. біол. наук, в.о. завідувача відділу природної і культурної флори. Email: chipiljak@i.ua Коршиков Іван Іванович, д-р біол. наук, професор, директор. Email: garden7@meta.ua

Лещенюк Олена Миколаївна, провідний інженер відділу природної та культурної флори. Email: fedorova8@bigmir.net Лінкевич Олена Олександрівна, провідний інженер відділу природної та культурної флори. Email: garden7@meta.ua

Цитування за ДСту: Чипиляк Т. Ф., Коршиков І. І., Лещенюк О. М., Лінкевич О. О. Хризантема дрібноквіткова в ландшафтних композиціях на Криворіжжі. Науковий вісник НЛтУ України. 2018, т. 28, № 3. С. 57-61.

Citation APA: Chipilyak, T. F., Korshikov, I. I., Leshcheniuk, E. M., \& Linckevych, O. O. (2018). Chrysanthemum Parviflorous in Landscape Compositions in Kryvyi Rig Region. Scientific Bulletin of UNFU, 28(3), 57-61. https://doi.org/10.15421/40280312 
методичними вказівками О. М. Авадяєвої, яка вивчала сезонні зміни колориту ландшафту і класифікувала простір відповідно до сезонних змін рослин, які його наповнюють (Avadyayeva, 2000). Монокультурний квітковий сад створювали за концепцією Л. І. Рубцова як квітник природного характеру великих розмірів зі значної кількості сортів одного виду багаторічних рослин (Rubtsov \& Laptev, 1971). Декоративні характеристики колекційних зразків хризантеми визначали за В. Ф. Горобцем (Horobets', 2003).

Результати дослідження. Хризантема має необмежені можливості в декоративному оформленні рекреаційних систем і часто її використовують у фітодизайні та озелененні міських кварталів. Сучасні сорти хризантеми мають складне гібридне походження, їх відносять до ботанічного виду Chrysanthemum indicum L. родини Asteraceae Dumort. (Horobets', 2003; D'yachenko, 2010). Протягом останніх п'яти років колекція хризантеми дрібноквіткової КБС значно поповнилася і складається з 98 різноманітних за декоративними якостями сортів. Тому виникла необхідність виділення окремої ділянки і створення експозиційно-рекреаційної зони - моносаду "Бал хризантем". Це важливо з огляду на те, що квіткові сади є багатофункціональними - вони можуть бути маточником, об'єктом для вивчення біологічних, морфологічних і декоративних особливостей рослин та місцем масового відпочинку людей. Об'єкт формували за законами ландшафтного мистецтва, враховуючи еколого-біологічні особливості рослин.

Під час оформлення різнопланових ландшафтних композицій дерева та кущі слугують об'ємним фоном, на якому з більшою виразністю виділяються трав'янисті багаторічники, які використовують для створення зорових переходів від дерев та кущів до більш низьких рослин та газону (Guzenko et al., 1985). Формування сезонного моносаду-квітника підпорядковують загальному художньому задуму території, що пов'язано з розміщенням та особливостями деревно-чагарникових угруповань у просторовій композиції саду. Вдало поєднані у груповій посадці рослини підкреслюють та доповнюють найвиразніші декоративні властивості одне одного (Lazarev \& Lazareva, 2005). Тому під час планування проекту задумано облаштувати нову осінню квіткову композицію в межах пейзажного простору вже наявних базових ландшафтних ділянок території Саду.

Розробили концепцію, в основу якої втілили ідею того, що хризантема в Японії є символом Сонця, а саме слово у перекладі 3 грецької означає "золота квітка" ("chrysos" - золото і "anthemos" - квітка). Тобто схемою експозиції $є$ сонячний диск із променями, які від нього виходять. Композиційно моносад "Бал хризантем" представлено групами сортів хризантеми різної величини, об'єднаних між собою загальним архітектурно-планувальним рішенням. Під час вибору території дотримувалися таких вимог: невід'ємним елементом новоствореної композиції є деревно-чагарникові рослини, які утворюють своєрідну рамку для моносаду в садовому пейзажі; рівнинний рельєф ділянки, який дає змогу оглядати експозицію з усіх боків; територія експозиції має сприятливі грунтово-гідрологічні умови, захищена від вітрів і відкрита з південного боку; в загальному комплексі обов'язкова наявність дорожньо-стежкової мережі та місць короткочасного відпочинку (Rubtsov \& Laptev, 1971). Виділена ділянка у формі трапеції, площею
0,25 га, відповідала вищеозначеним вимогам і знаходилася поряд із колекційними ділянками квітниково-декоративних рослин, які прикрашали моносад протягом усього вегетаційного періоду. Впродовж березня-серпня 2017 р. проводили підготовку території для експозиції видаляли бур'яни, вносили добриво, планували грунт. Облаштування території безпосередньо для насадження вирощених кущів хризантеми розпочали на початку вересня - проклали пішохідні оглядові доріжки з тротуарної плитки та природного каменю, встановили лави для відпочинку та контейнери для сміття. Дорожнє покриття вибрали з приглушених відтінків сірого і кремовокоричневого кольорів, що врівноважило яскраві насичені тони хризантеми, які домінували в експозиції (Nefedov, 2002). Доріжки поділили експозиційну ділянку на різні за формою і розмірами частини і дали можливість відвідувачам оглянути всі сорти хризантеми.

Ключовою вимогою під час створення ландшафтних композицій є чітка структура малюнка і колірного рішення, тобто максимально сильне емоційне враження будуть надавати цілісні квіткові плями простої конфігурації (Kucheryavyy, 2005), тому ми висаджували кущі хризантем невеликими кольоровими плямами в одній площині з нечіткими кордонами, що дало ілюзію "природних" ландшафтів. Розташовуючи рослини на експозиції, враховували правила садово-паркового мистец$m в a$ - закони контрасту, розміщення кольорових акцентів, використання принципу чергування яскравих картин із паузами або інтервалами, поєднання сортів за забарвленням квітки, габітусом та висотою куща. У виборі колористичної гами ми намагалися показати різноманіття кольорів квітучої хризантеми. За кольоровою гамою використані сорти (близько 70) поділили на п'ять груп: червоних відтінків (квітки бордові, темно-червоні, яскраво-червоні), теракотових (квітки теракотові, оранжево-коричневі, жовтогарячі), жовтих (квітки насичено-жовті, жовті, лимонні), рожевих (квітки темнорожеві, лілові, ніжно-рожеві) та білих відтінків (квітки білі, кремові) (рис. 1). Майже в однаковій кількості (2226 \%) було представлено сорти червоних, оранжевих та рожевих кольорів, найменше - жовтих відтінків. Рослини хризантеми симетрично й асиметрично розміщено в рівновазі відносно композиційного центру, для якого було підібрано сорти червоно-теракотової кольорової гами - високий сорт 'Vitchyzna' з бордовими квітками, середньо-рослий червоний сорт 'Lipstik' і жовтогарячий 'Koreyanochka', що дало можливість зробити акцент на центральній частині експозиції.

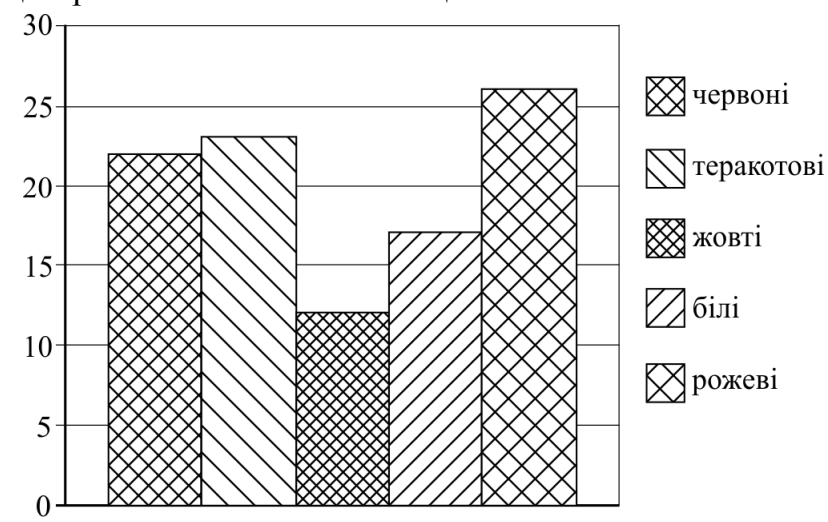

Рис. 1. Поділ сортів Chrysanthemum indicum L. за кольором квітки у моносаді "Бал хризантем" на території Криворізького ботанічного саду НАН України (\%) 
Оскільки забарвлення і форма квітки має істотне значення під час створення декоративного ефекту в композиційному рішенні, ми для "посилення" звучання основного кольору підібрали як близькі за тоном, так і контрастні кольори - поєднання протилежних кольорів підсилило інтенсивність один одного і створило гармонійні контрасти. Так, 312 відокремлених доріжками, одна від одної, частин експозиції, на чотирьох були поєднані сорти, близькі за тоном: рожевої групи - темно-ліловий 'Leliya', рожевий 'Nova Era', насичено-рожевий 'Kosmichna'; жовтої - яскраво-жовтий 'Opal', оранжево-жовтий 'Kolobok', темно-жовтий 'Knopa'; білих відтінків - білий 'Vindavait', біло-кремовий 'Вуеlosnyezhka', сніжно-білий 'Umka'; теракотової групи матово-теракотовий 'Zhuravlynka', оранжево-теракотовий 'Hayduk', оранжево-червоний 'Ozherel'ye'. Такі кольорові плями створили відчуття спокою, виконали роль фону для сприйняття більш яскравих, контрастних поєднань.

Під час створення експозиції врахували габітус та висоту рослин. За висотою кущів сорти хризантеми дрібноквіткової поділяють на три групи - низькорослі (15-40 см), середньорослі (40-80 cм) та високорослі (вище $80 \mathrm{~cm}$ ). Низькорослі сорти ('Malyutka', 'Tirana Red', 'Vivilli Vayt', 'Boreal' Violet' та ін.) розміщено на передньому плані експозиційної ділянки. За допомогою середньорослих сортів ('Eri', 'Lumina', 'Terakota', 'Chervona shapochka', 'Iolanta' та ін.) досягнуто ефект об'єму i плавного переходу до високорослих сортів ('Zarechanka', 'Leb'odushka', 'Tvinkel', 'Slav'yanochka'), які щільно висаджено на задньому плані ділянки для гармонійного завершення.

Автентичність кожної пори року досягається відповідним асортиментом рослин у період їх найвищої декоративності та привабливості. У нашій сезонній композиції "рослиною-маяком" була хризантема - квітникова культура осіннього терміну цвітіння, яке презентує зміну літа на осінь. Для досягнення максимального декоративного ефекту у визначені терміни (в умовах Криворіжжя - це кінець серпня - початок листопада) під час створення моносаду враховано терміни квітування сортів хризантеми. Зразки сортів раннього терміну цвітіння в наших умовах розквітали у кінці липня серпні. Це 'Nova Era', 'Meteoryt', 'Kosmichna', 'Zolote runo', 'Hranat' та ін. Сорти середнього терміну квітування, які наповнили композицію неперевершеним ароматом та багатством кольорів - бузкових, білих, рожевих, лілових, кармінових, яскраво-жовтих, теракотових, - розцвіли на початку осені. Це сорти: 'Rozhevi Mriyi', 'Kolobok', 'Vivilli Pink', 'Sonechko', 'Vrodlyva' та ін. Найбільш численна група середньопізніх сортів - 'Zirnytsya', 'Leliya', 'Hir-Har', 'Ozheryel'ye', 'Zhuravlynka', 'Karmin' та інші - неймовірне багатство забарвлення проявила 3 кінця вересня - на початку жовтня. Тоді ж настав пік декоративності експозиції. Пізні сорти цвіли від середини жовтня аж до кінця листопада - 'Vitchyzna', 'Hebe', 'Byelosnyezhka', 'Tsaryevna Lyebyed", 'Yuriy Bahatikov' та ін.

Головним принципом, який забезпечує високий художній рівень квітникового оформлення, $є$ єдність ідейно-композиційного задуму, пропорційність, масштабність та контрастність, оскільки ландшафт - складна інтегральна система елементарних структур (Levon, 2008). Під час створення моносадів, окрім сортового різноманіття та розташування рослин в експозиції, важ- ливими чинниками $є$ фон, колір та форма супутніх рослин, які повинні підсилити та підкреслити декоративний ефект основної культури. У складі новоствореної ландшафтної композиції домінантом була хризантема, яка гармонійно поєдналася 3 уже створеним садовопарковим ландшафтом. 3 північної та східної сторін сезонну експозицію "Бал хризантем" обрамляли ділянки колекційних рослин родин Betuleaceae S. F. та Oleaceae Hoffmg. et Link., західної - експозиція хвойних порід "Коніферетум" (рис. 2). Восени супутні листопадні та хвойні породи підкреслили і посилили архітектурно-художні переваги квіткової композиції (див. рис. 2). Включення експозиції "Бал хризантем" у вже створені на цей час мікроландшафтні дендрокомпозиції довершили загальну приголомшливу красу осіннього Саду (Mazur et al., 2018). Завдяки осінньому жовто-червоному забарвленню різних видів дерев, різноманітним формам їх крон, темно-зеленому фону хвойних порід, квіткова композиція, з різних за формою та кольоровою гамою квіток хризантем, набула надзвичайної краси. Експозиція "Бал хризантем" стала чудовим доповненням до дерев і кущів, органічно вписалася в загальний пейзаж, забезпечуючи близьку до природних плавність ліній ландшафту вільного стилю. Використаний принцип куліс дав можливість досягнути більшої виразності пейзажу й поступового його розкриття, вирішити завдання організації простору і масштабу.

Для внесення у культур-фітоценози Криворіжжя яскравого аспекту, в м. Кривий Ріг, м. Зеленодольськ та с. Червоне Криворізького р-ну Дніпропетровської обл. за допомогою наукових співробітників створено різнопланові квіткові композиції за участі різноманітних сортів хризантеми дрібноквіткової. Так, на території поблизу міськвиконкому Кривого Рогу із хризантеми створено осінній квітник "Веселка" партерного типу, у Тернівському районі міста на квітниках Індустріального коледжу ДВНЗ "Криворізький національний університет" зі середньорослих сортів створено бордюрні посадки, а біля виконкому Тернівської у місті ради низькорослі сорти прикрасили посадки колоноподібного ялівцю. У селищах Криворізького району кущами хризантеми прикрашено державні заклади та пам'ятники різної тематики.

Висновки. Проведений аналіз і визначення методів і прийомів ландшафтної архітектури та врахування еколого-біологічних особливостей сортів Chrysanthemum indicum L. дало змогу створити на території Криворізького ботанічного саду осінній моносад, який облаштовано в межах вже наявних мікроландшафтних дендрокомпозицій з рослин родин Betuleaceae S. F., Pinaceae Lindl., Oleaceae Hoffmg., Cupressaceae Bartl. Під час вибору ділянки враховано такі вимоги: огляд експозиції з усіх боків, грунтово-кліматичні умови території Саду, наявність доріжок та місць короткочасного відпочинку. Рослини хризантеми знаходилися в рівновазі відносно композиційного центру і були висаджені невеликими кольоровими плямами в одній площині 3 нечіткими кордонами. На експозиції сорти поєднано за забарвленням квітки, габітусом та висотою куща 3 використанням принципу чергування яскравих картин 3 паузами або інтервалами. Моносад "Бал хризантем" органічно вписався в загальний пейзаж, забезпечуючи близьку до природних плавність ліній ландшафту вільного стилю. 


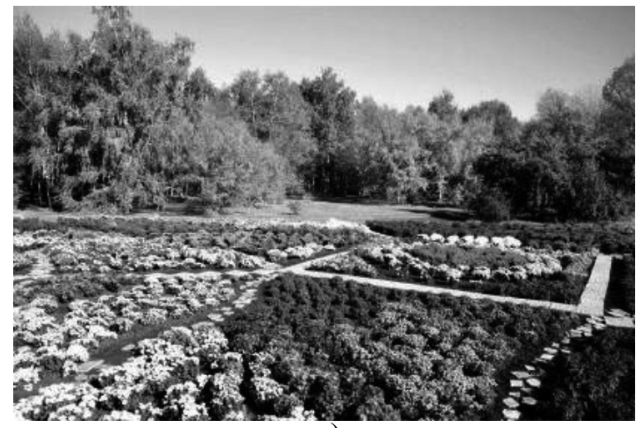

a)

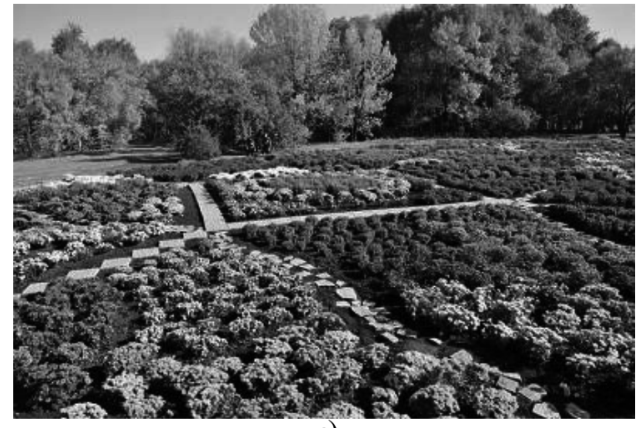

6)

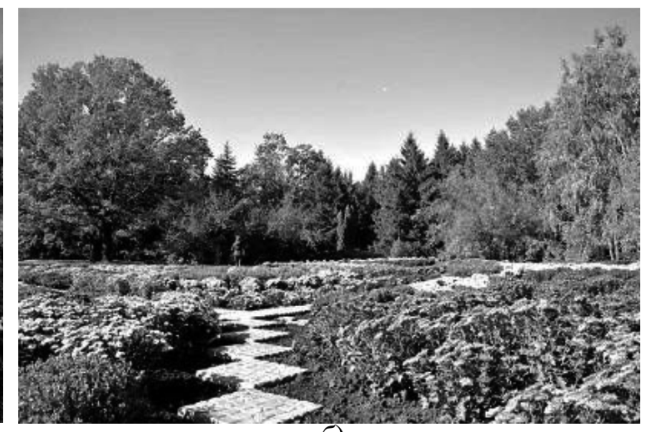

б)

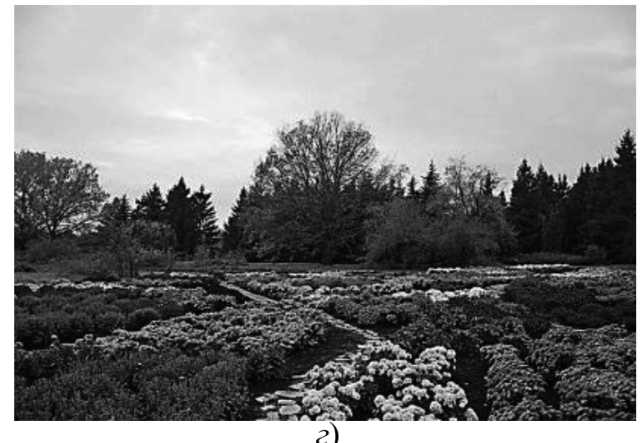

Рис. 2. Ландшафтна сезонна композиція "Бал хризантем" у ландшафті Криворізького ботанічного саду НАН України:

а) вид на колекцію родини Betuleaceae S. F.; б) вид на колекцію родини Pinaceae Lindl.; в) вид на колекцію родини Oleaceae Hoffmg. et Link.; г) вид на "Коніферетум"

Використання сортів Chrysanthemum indicum колекції Криворізького ботанічного саду НАН України як монокультури (моносад "Бал хризантем") та як доповнення до інших рослин (квітники безперервного цвітіння, бордюрні посадки) сприяє створенню сучасних високодекоративних культур-фітоценозів на території об'єктів різноманітного функціонального призначення Криворіжжя.

\section{Перелік використаних джерел}

Avadyayeva, Ye. N. (2000). Russkiy landshaftnyy dizayn. Moscow: Olma-Press. 388 p. [In Russian].

Cherevchenko, T. M. (2002). Botanichni sady ta dendroparky holovni oseredky introduktsiynykh doslidzhen' ta zberezhennya riznomanittya Roslyn. Mater. II Mizhnar. konf. "Teoretychni ta prykladni aspekty introduktsiyi roslyn i zelenoho budivnytstva". Uman': Dendrolohichnyy park "Sofiyivka", 11-16. [In Ukrainian].

Chypylyak, T. F., Mazura, M. Yu., Bereslavska, O. O., \& Leshchenyuk, O. M. (2014). Flower Design of Parks and Squares in Krivoy Rog: Status, Problems and Recommendations for Improvement. Scientific Bulletin of UNFU, 24(4), 164-169. [In Ukrainian].
Dyachenko, N. G. (2010). Khrizantemy koreyskiye. Moscow: Izdatelskiy Dom MSP. 32 p. [In Russian].

Guzenko, T. G., Ganzha, M. G., \& Kotova, I. Yu. (1985). Dekorativnoye sadovodstvo i sadovo-parkovoye stroitelstvo. Kyiv: Budivelnik. 182 p. [In Russian].

Horobets, V. F. (2003). Khryzantemy vidkrytoho hruntu. Kvity Ukrayiny, 6(70), 42 p. [In Ukrainian].

Kucheryavyy, V. P. (2005). Ozelenennya naselenykh mists. Lviv: Svit. 455 p. [In Ukrainian].

Lazarev, A. H., \& Lazareva, E. V. (2005). Landshaftnaya arkhytektura. Yzd.: Fenyks. 282 p. [In Russian].

Levon, F. M. (2008). Zeleni nasadzhennya $v$ antropohenno transformovanomu seredovyshchi. Kyiv: NNTS IAE. 364 p. [In Ukrainian].

Mazur, A. O., Korshykov, I. I., Yukhymenko, Yu. S., Krasnoshtan, O. V., Danylchuk, N. M., \& Laptyeva, O. V. (2018). Introduktsiynyy potentsial khvoynykh $\mathrm{v}$ mikrolandshaftnykh dendrokompozytsiyakh Kryvorizkoho botanichnoho sadu NAN Ukrayiny. Scientific Journal ScienceRise: Biological Science, 1(10), 20-25. [In Ukrainian].

Nefedov, V. A. (2002). Landshaftnyy dizayn $i$ ustoychivost sredy. Sankt-Peterburg: Poligrafist. 295 p. [In Russian].

Rubtsov, L. I., \& Laptev, A. A. (1971). Spravochnik po zelenomu stroitelstvu Rubtsov. Kyiv: Stroitel, 341 p. [In Russian].

Т. Ф. Чипиляк, И. И. Коршиков, Е. Н. Лещенюк, Е. А. Линкевич Криворожский ботанический сад, НАН Украины, г. Кривой Рог, Украина

\section{ХРИЗАНТЕМА МЕЛКОЦВЕТКОВАЯ В ЛАНДШАФТНЫХ КОМПОЗИЦИЯХ НА КРИВОРОЖЬЕ}

Неотъемлемым компонентом садово-парковых насаждений является цветочное оформление, как художественный элемент благоустройства. Коллекция Chrysanthemum indicum L. Криворожского ботанического сада НАН Украины (КБС) состоит з 98 разнообразных культиваров, которые в ландшафтном дизайне ценят за декоративность и универсальность использования. Определены методы и приемы практического использования садовой хризантемы в ландшафтах Криворожского региона. С этой целью на территории КБС был создан осенний цветник "Бал хризантем" площадью 0,25 га в пределах уже существующих микроландшафтных дендрокомпозиций. При выборе участка были учтены такие требования: осмотр экспозиции со всех сторон, благоприятные почвенно-климатические условия территории Сада, наличие дорожек и мест кратковременного отдыха. Растения хризантемы размещены в равновесии относительно центра и были высажены небольшими цветными пятнами в одной плоскости с нечёткими границами. На экспозиции сорта были объединены по окраске цветка, ширине и высоте растения с использованием принципа чередования ярких картин с паузами или интервалами. Использование сортов Chrysanthemum indicum в качестве монокультуры (КБС - моносад) и как дополнение к другим растениям (г. Кривой Рог, Криворожский район - осенние цветники, бордюрные посадки, обрамление хвойных растений) способствует созданию современных высокодекоративных культурфитоценозов на территории Криворожья.

Ключевые слова: садовая хризантема; моносад; фитоландшафты; Криворожский регион. 
T. F. Chipilyak, I. I. Korshikov, E. M. Leshcheniuk, O. O. Linckevych Kryvyi Rih Botanical Garden, NAS Ukraine, Kryvyi Rih, Ukraine

\section{CHRYSANTHEMUM PARVIFLOROUS IN LANDSCAPE COMPOSITIONS IN KRYVYI RIG REGION}

The development of a modern city requires new models and approaches to the implementation of greening systems which help ensure the comfortable existence of man in anthropogenic disturbed environment. An integral component of landscape plantings is design of flower beds, as an artistic element of accomplishment. Chrysanthemum parviflorous is the most decorative crop of the autumn period, and varieties of Chrysanthemum indicum L. collected in Kryvyi Rih Botanical Garden of NAS of Ukraine may be a vivid autumn landscape element of the region. Therefore, our purpose was to determine methods and techniques of practical use of garden chrysanthemum in landscapes of Kryvyi Rih region. The object of the research is representatives of the genus Chrysanthemum (Dendranthema (DC), Desmoul., Chrysanthemum L.) collection of the Kryvyi Rig Botanical Garden of the NAS of Ukraine. The classification of the landscape according to seasonal changes was carried out according to the methodical instructions of O. Avadyayeva. Mono-cultural flower garden was created according to the concept of L. Rubtsov. The decorative characteristics of chrysanthemums were determined by V. Horobets. The results of the practical use of the representatives of Chrysanthemum indicum L. in the formation of vegetation landscape in Kryvyi Rig region are presented. The principles and techniques of creation of the autumn mono garden "The Ball of Chrysanthemum" on the territory of the Kryvyi Rig Botanical Garden are determined. Formation of a mono garden is subject to the general artistic design of the territory and is associated with the placement and features of wood-shrub groups in the spatial composition of the garden. When selecting areas we considered the following requirements: review of the exposition on all sides, favourable soil-climatic conditions of the territory of the Garden, and availability of tracks and places of short-term rest. The scheme of the exposition was represented by a solar disk with rays. Chrysanthemum plants are in equilibrium concerning the centre and were planted with small coloured spots in one plane with fuzzy boundaries. The rules of garden art are taken into account. The colour varieties are divided into five groups such as red, terracotta, yellow, pink and white. Almost equal numbers (22-26\%) were represented by varieties of red, orange and pink, the least - yellow tints. Symmetrical and asymmetrical chrysanthemum plants were placed in equilibrium relative to the composite centre for which we selected varieties of red and terracotta colours. The current composition of trees and shrubs form a "cadre" for mono garden in garden landscapes. To conclude, we identified methods using varieties of garden chrysanthemums collection of Kriviy Rig Botanical Garden of NAS of Ukraine as a monoculture (mono garden "The Ball of Chrysanthemum") and as a supplement to other plants (flower beds of continuous flowering, border planting). The use of varieties of Chrysanthemum indicum contributes to the creation of modern highly decorative cultivated phytocoenoses on the territory of different functional purpose of Kryvyi Rig region.

Keywords: chrysanthemum garden; mono garden; phyto-landscapes; Kryvyi Rig region. 